\title{
A PREFACE FOR STUDENTS, WITH A NOTE TO EVERYONE ELSE
}

Most law students venture outside of their assigned casebooks only to find something that will make their lives easier: a study guide, an outline, a nutshell. In this book, I will ask you to take exactly the opposite course. The casebooks that are used in most courses today hide much of the life of the law. They focus on brief excerpts from appellate opinions, as if you will find in such highly edited passages the legal significance of the cases. The excerpts are reduced to propositions of law that students outline and try to remember. Students are often left puzzling about this form of presentation. Why bother with presenting even a part of the opinion, if the substantive point can be reduced to a proposition? Why hide the ball behind the bits and pieces of judicial opinions? If the task is to discern the kernel of law within the chaff of the opinion, the endless proliferation of outlines, case notes, study guides, and hornbooks is hardly surprising.

The original promise of the casebook method was to immerse students in the richness of the law in action, the law as it actually works in the details of human interactions. That promise has long gone unfulfilled as the casebook has grown in size (and cost), while shifting its focus to doctrinal comprehensiveness. Instead of heading for an outline, I will urge you to head to the opinions themselves. The casebook will teach you a lot of law, but it will not teach you how to read an opinion. The casebook edits opinions down to manageable excerpts, arranged to make a series of discrete points filling in an outline of a substantive area of law. The law, however, does not come this way in ordinary life. In the actual practice of law, no one tells you which parts of the opinion are the important ones. No one even tells you which are the important opinions. You won't find the answers in a casebook or a course outline. Nor are you likely to find it through a word search on Lexis or Westlaw. 
No one can do this work for you because legal problems do not appear with labels already attached. Someone walks into your office with a complaint about an employer, a neighbor, or a government official. Your job will be to translate that complaint into a legal problem. Until you know what kind of a problem it is, you will not be able to figure out what sort of legal solutions may be available. You accomplish this translation by reconstructing the facts in light of the available law. This means emphasizing certain facts and relationships while de-emphasizing others. Law and facts have to inform each other not just at the point of judgment, but before you can take even your first step toward a resolution of the problem. Your client may be more worried about the offense to his dignity than the violation of his property, but offenses to dignity may not be legally cognizable. He may be brokenhearted, but the law offers no cure for that injury.

Law school is not just about learning legal doctrine. More importantly, it is about learning how to move back and forth between facts and law such that each informs the other. The effect of this movement is to make both sides of the equation more complex. Because law does not work as abstract doctrine, it does not come with distinct borders. There is always more law that can be brought to bear. There are more opinions that can be read, more arguments that can be made. A lawyer needs to learn when to stop reading and start arguing. You stop when you have learned enough to make a persuasive case. Similarly, there are always multiple ways to give an account of the facts. Legal argument, for the most part, works through analogy and distinction. We figure out what to do in one case by understanding how its facts stand with respect to those of past cases (precedents) and future possible cases (hypotheticals). Competing analogies rely on different ways of presenting the facts; these differences in turn lead us to understand the law differently. There is no right or wrong way to do this. The right way is that which persuades others to see the case as you do.

You cannot learn how to deal with the superabundance of law or how to build persuasive analogies by reading only excerpts in a case- 
book. Those excerpts have been stripped of most of the factual details; they have been artificially isolated from the multiple connections by which they are tied to other opinions. Opinions are great pedagogical resources because from them one can learn how facts and law must be woven into a single narrative. One learns from them that law is a practice of persuasion. The opinion is written to persuade a community that must see the reasons for the law and, more importantly, must accept the law as its own. Opinions can teach none of this if they are read only for the doctrinal positions they set forth.

Accordingly, one of the skills that a lawyer must develop is that of knowing how to read opinions-even long ones. The lawyer is not reading in order to find that single proposition of law for which the case stands. If that were all there were to it, judges would not bother to write opinions that were more than formal statements of the relevant law. Indeed, traditionally judges on the European continent wrote short opinions that listed propositions in a strictly formal manner. Law was applied to facts, as if it were a matter of logical deduction or syllogistic reasoning. Writers of opinions did not reason by analogy, which appeared too open-ended and contestable for continental ideas of the limits of judicial authority. Nor was there a practice of public disagreement on the bench. Dissents would have suggested the contestable character of the law. Instead, judges wrote in a manner that looked a good deal like the outlines that you probably generate for yourselves or buy in preparation for an exam.

What those judges were doing out of ideological conviction, we are doing in law school for the sake of pedagogical convenience. Of course, some of this is necessary since there is a lot of law to learn and students cannot possibly read every opinion of every case they study. At some point, however, you must turn to the opinions themselves. Learning the law is most like learning a new language: both require engagement with the actual practice. ${ }^{1}$ You don't learn a language by outlining formal rules and memorizing words. You learn the language by putting it to use; you learn how to describe a situation or to work your way through a transaction by actually using the language. The same is true of the law: you must learn by doing. 
This approach to legal education has largely motivated the development of clinical education. But the line between clinical and classroom education is a false line. The pedagogic techniques may be different, but there simply is no law in the abstract. All law is embedded in facts; all law is contextual. For every principle, there are exceptions; for every formal statement of law, there are available other statements that point in different directions. You read opinions not just because they are a source from which you are to derive abstract norms but because they show us what the law is-a practice of persuasion in which norms and facts work together. If you want to learn how to think creatively within the law, or if you believe that law has something to do with the practice of persuasion in a democratic community, then you must turn to the opinions. This book is meant to help you understand what it is you will find there. My aim is to analyze and explain where and how the persuasive quality of the opinion does its work.

Most of my examples are drawn from one particular category of judicial opinions: those that involve constitutional law. Some decades ago, Karl Llewellyn took up a similar pedagogical task but turned mostly to commercial law and contract cases. ${ }^{2}$ He drew upon these examples because they were the cases he knew best. I turn to opinions dealing with constitutional law because they are the cases I know best. They are also the opinions of which Americans today are likely to think when they consider the power and role of the courts, and of the Supreme Court in particular. These opinions have come to set the pattern of expectations of a court, both for judges and for the wider community.

This is not, however, a book about constitutional law. I offer no view of the field and make no effort to be comprehensive. My concern is with the opinion as the work product of the courts and as a resource for legal argument. What I have to say about the skills necessary to read these particular opinions is no less true of other opinions that deal with the problems of interpreting legal texts, whether statutes, regulations, or judicial precedents. The canons of interpretation and the practices of deference to other decision makers may 
not always be the same, but the problems of narrative and voice, of building a persuasive argument by negotiating between authoritative texts and precedents interpreting those texts, and of setting the context within which one sees the facts remain the same. The stakes may not be as high as in constitutional cases, but the opinion as a literary genre demands of us the same sort of reading skills wherever it appears. ${ }^{3}$

I like to think of a successful reading as getting the opinion to sing. There is music in the law. Its players are the judges, and its audience is the well-trained lawyer. Unless you have a trained ear, you will not hear the melody. No single book can teach you how to hear the music of the courts, but it can make a start. I try to point you in the right direction by sharing a reading of some prominent and some not so prominent opinions. If you want to make the best use of this book, I suggest that you read the entire opinion along with my discussion.

Now a word for everyone else. There is a genre of academic, legal writing in which an introductory work is no less a serious work on law. The most famous text in this tradition is Karl Llewellyn's The Bramble Bush, but there are also Edward Levi's Introduction to Legal Reasoning, Oliver Wendell Holmes's The Path of the Law, Benjamin Cardozo's The Nature of the Fudicial Process, and H. L. A. Hart's The Concept of Law. More broadly, one might include Ronald Dworkin's Law's Empire and Roberto Unger's What Should Legal Analysis Become? Law shares this character with philosophy. One begins to study philosophy by reading Plato's dialogues. The philosopher could happily spend a career with those same texts. The law student begins with Marbury or Palsgraf. The law professor is still reading those same opinions.

One wants to explain to the student what the law is, how it comes to be, maintains itself, and changes in a complex world that is itself in constant flux. These are questions for a lifetime of study. In law school, the simplest issues are also the deepest: questions of the nature of law, judicial role, precedent, and authority. These are not just the starting points of an inquiry into law; rather, they define the field. 
In neither philosophy nor law is there a step-by-step, incremental approach to the subject by which we move from the simple to the more complex. The pedagogical task in these disciplines is entirely different from that in the sciences, where one builds up a body of knowledge. Some contemporary academics are bringing the tools of the social sciences-particularly economics - to the study of law. Whatever the success of that endeavor in the academy, it does not go to the heart of our legal practice, which remains a text-based process of persuasion through interpretation. Economists may have lots to say about what laws and administrative regulations should be, but they have little to say to the practicing lawyer or judge.

If law is a practice of interpretation, then teaching the law shares a good deal with teaching other humanistic disciplines. ${ }^{4}$ There is no way to teach an interpretive discipline except by treating one's students as if they are already partners in the inquiry. The Socratic method may look hierarchical from the outside, but ideally it is a reciprocity of discourse in pursuit of a common inquiry. Its model is answer and response; it requires that each side listen to the other. Listening, each is capable of persuading and being persuaded by the other. Together, professor and student are pursuing an interpretation of fact and law.

My effort has, accordingly, been to write a book that is accessible to students and simultaneously of interest to scholars. Some of what I have to say covers familiar ground; surely most of the opinions I discuss are well known. The organization and approach are likely to be unfamiliar. I approach the opinion as a form of rhetorical address performing the broadly political task of maintaining belief in selfgovernment through law. ${ }^{5}$ An opinion announces a judgment, but the content of that judgment is the least interesting aspect of the opinion from the perspective of this work. Here, dicta are as important as holding.

In chapters 2 and 3, I take up issues of narrative and voice. Every opinion relies on narrative; every narrative constructs a voice. Reading the opinion, whom do we hear? These are critical elements for understanding the way in which an opinion claims a kind of demo- 
cratic legitimacy. In chapters 4 and 5, I turn to issues of the development of doctrine, that is, to assertions of law and fact. An opinion is always situated with respect to some body of doctrine, which it can create, maintain, or destroy. I explore the work of the opinion in each of these three dimensions. Similarly, an opinion must situate itself with respect to some set of facts. The most important facts of an opinion are not the evidentiary findings of the trial court. Rather, they are those that set the context or what I call the "horizon." Without this common horizon, analogical argument would be impossible, for in the abstract everything is both alike and different. One important consequence of the situated character of an opinion is that law can never be more than relatively autonomous with respect to other forms of knowledge and belief. This is just another way of saying that law is not a science but a practice of living together.

No doubt, law students today must learn a good deal more than how to read an opinion. Law schools must teach fluency in policy construction, administrative proceedings, and regulatory process; they must teach specific subject matters-from health care to environmental protection. Students must know how to read a statute as well as an opinion; they must know what to argue to a regulatory body as well as to a judge. To those who teach in these fields, my approach may seem overly jurocentric — a bit old-fashioned, as if we still lived in the age of the common law. They need have no fears that the approach I set forth here will take legal pedagogy backward. The casebook is not about to disappear, particularly in those fields where the very point of the course is to offer a broad survey of the law. I am proposing to teach a practice of interpretation, not an entire curriculum. I am trying to recover and hold on to a disciplinary approach that is in danger of disappearing.

The need for such an act of recovery is pressing. As I write this, the Supreme Court has handed down McCutcheon v. Federal Election Commission, declaring unconstitutional limits on overall campaign contributions by individuals. ${ }^{6}$ The various opinions in the case run to about a hundred pages. While the popular press asks which interest groups won, collectively we-all of us-are very much in need of 
a way to evaluate these opinions apart from the competition of political parties. What are the Justices doing in these opinions? What should they be doing, and are they succeeding or failing in that task? If we are to understand our own practices of self-government under law, these are necessary questions. In this book, I try to answer them.

At stake in this book, therefore, is not just how we should teach law, but how we should understand law. Law students today are likely to think that law is either a matter of doctrine to be memorized or of politics to be disputed. I aim to open a space in between, where interpretation and persuasion have their own standards. If I am successful, this approach should feel to most lawyers less like something new than like a recovery of something familiar. It should be recognizable and persuasive to others as well, for the rule of law is something we have been doing together for a very long time. 